\title{
Application of Taguchi Technique in Optimization of Machining Parameters in Turning of Al6463 Aluminium Alloy
}

\author{
Amardeepak $^{1}$, Narayana B Doddapattar ${ }^{2}$ \\ ${ }^{1}$ Research Scholar, Mechanical Engineering, SSIT,Tumkur,Karnataka, India, \\ ${ }^{2}$ Professor,The Oxford College of Engineering, Bangalore,Karnataka, India,
}

\begin{abstract}
An attempt was made to conduct an experimental study of aluminum alloys using the Taguchi technique to search for and correlate technological factors with the economics of the processing process. Improvement of one parameter leads to deterioration of other parameters, and optimization of several parameters is much more difficult. This article examines and presents the effect of changing processing parameters, such as speed, feed, cutting depth Material composition and nose radius of the tool on Al6463. First, the optimal location of the five parameters was determined using the L16 configuration of the Taguchi method with a four-level variation. Two sets of experiments were conducted considering the change in Mg and Si composition of the Al6463 alloy. After completion of the Experimentation, the values are documented and compared using the software for statistical analysis.
\end{abstract}

Keywords: Machinability; Taguchi technique; cutting parameters; Al6463

\section{Introduction}

Traditionally, the machinability of materials involves tool life, cutting forces, productivity or chip formation, with less attention paid to particle emission. In this work, the authors address the machinability of aluminium alloys from several points of view, including cutting forces, chip formation and segmentation and metallic particle emission.The main properties which make aluminium a valuable material are lightweight, strength, recyclability, corrosion resistance, durability, ductility, formability and conductivity. Due to this unique combination of properties, the variety of applications of aluminium continues to increase.

The analysis of the data during manufacturing by using suitable statistical designs is of high importance for precise evaluation to be obtained from the process. Design and methods such as factorial design, response surface methodology and Taguchi methods are now widely in use in place of one-factor-at-a-time experimental approach which is time consuming and exorbitant in cost. Lalwaniet al., [1] studied the effect of cutting parameters in turning on cutting forces and surface roughness. Dickinson, Grieve et al., and Fischer and Elrod developed a turning model in which tool nose radius and feed rate are taken into account but cutting speed is ignored. Thomas et al., used built up edge formation occurring during dry turning mild carbon steel and a full factorial design, taking into account the three-level interactions between the independent variables. Yang and Tarng[3] have conducted study on optimal cutting parameters using Taguchi method in turning. Nianet al. [7]investigated the optimization of CNC turning operations by Taguchi method with multiple performance characteristics. Lin et al., developed an objective network model to estimate the surface roughness and cutting forces. Wang et al.,[9] investigated the effect of tool nose vibration on surface roughness during turning theoretically and experimentally.

Surface finish is one of the most important quality characteristics in manufacturing industries which influences the performance of mechanical parts as well as production cost. In order to improve the product quality and efficiency in machining, recently, there has been intensive computation focusing on surface roughness at international level. This computation can be observed in turning processes especially in aerospace and automotive industry by increasing the alternative solution for obtaining better surface roughness. A good quality turning surface can lead to improvement in strength properties such as fatigue strength, corrosion resistance and thermal resistance. In addition, the final surface roughness also affects several function attributes of parts like friction, wearing, light reflection, heat transmission, coating and ability of distributing and holding a lubricant. According to Kromanis, A. and Krizbergs, the quality of surface plays a very important role in functionality of produced part. Therefore, it is necessary to develop methods, which can be used for the prediction of the surface roughness according to technological parameters.

\section{Experimental Study}

The as-received A16463T6 alloy was used in this study and its chemical composition is given in the Table 1. Two sets of experiments were conducted considering the change in $\mathrm{Mg}$ and $\mathrm{Si}$ composition of the Al6463 alloy. Al6463 aluminium alloy is an alloy in the wrought aluminium-magnesium-silicon family (6000 or $6 x x x$ series). It is related to 6063 aluminium alloys (Aluminium Association designations that only differ in 


\section{International Journal of Science and Research (IJSR) \\ ISSN (Online): 2319-7064}

Index Copernicus Value (2015): 78.96 | Impact Factor (2015): 6.391

the second digit are variations on the same alloy), but unlike 6063 it is generally not formed using any processes other than extrusion. It cannot be work hardened, but is commonly heat treated to produce tempers with a higher strength but lower ductility. Like 6063, it is often used in architectural applications.

Table 1: Chemical Composition 6463 Aluminum Alloys In Weight Percentage

\begin{tabular}{|c|c|c|c|c|c|c|c|c|c|}
\hline $\begin{array}{c}\text { Weight } \\
\%\end{array}$ & $\mathrm{Al}$ & $\mathrm{Si}$ & $\mathrm{Fe}$ & $\mathrm{Cu}$ & $\mathrm{Mn}$ & $\mathrm{Mg}$ & $\mathrm{Zn}$ & $\begin{array}{c}\text { Other } \\
\text { Each }\end{array}$ & $\begin{array}{c}\text { Others } \\
\text { Total }\end{array}$ \\
\hline 6463 & $\mathrm{Bal}$ & $\begin{array}{c}0.20 / \\
0.60\end{array}$ & $\begin{array}{c}0.15 \\
\mathrm{max}\end{array}$ & $\begin{array}{c}0.20 \\
\max \end{array}$ & $\begin{array}{c}0.05 \\
\max \end{array}$ & $\begin{array}{c}0.45 / \\
0.90\end{array}$ & $\begin{array}{c}0.05 \\
\max \end{array}$ & $\begin{array}{c}0.05 \\
\max \end{array}$ & $\begin{array}{c}0.15 \\
\max \end{array}$ \\
\hline
\end{tabular}

\section{Taguchi Technique}

\subsection{L16 technique}

Experimental design was done using Taguchi method under the L16 orthogonal array. Hence, it has been possible to reach more comprehensive results with doing fewer experiments. In this sense, time and money have been used more efficiently [7-8]. In the determination of the characteristics of the quality as the rates of surface roughness to be measured, MRR, cutting time, and cutting force were required to be minimum, "less is more" principle has been applied among the quality values expected to be reached at the end of the experiments.

The control parameters were cutting speed $(\mathrm{V})$, feed rate (f). Four levels were specified for each of the factors as indicated in Table 2. The orthogonal array chosen was L16, which has 16 rows corresponding to the number of parameter combinations. The first column was assigned to the cutting speed (V), the second column to the feed rate (f) and so on.

Table 2: Assignment Of The Levels To The Factors (Mg Composition)

\begin{tabular}{|c|c|c|c|c|c|c|}
\hline \multirow{2}{*}{ Cutting Parameters } & \multirow{2}{*}{ Unit } & \multirow{2}{*}{ Notation } & \multicolumn{5}{|c|}{ Limits } \\
\hline Feed rate $(A)$ & $\mathrm{mm} / \mathrm{rev}$ & $\mathrm{f}$ & 0.1 & 0.15 & 0.2 & 0.25 \\
\hline Speed $(B)$ & $\mathrm{RPM}$ & $\mathrm{N}$ & 500 & 1000 & 1500 & 2000 \\
\hline Depth of cut $(C)$ & $\mathrm{mm}$ & $\mathrm{d}$ & 0.25 & 0.5 & 0.75 & 1 \\
\hline $\begin{array}{c}\text { Material } \\
\text { Composition }(D)\end{array}$ & $\%$ & $\% \mathrm{Mg}$ & 0.5 & 0.625 & 0.75 & 0.875 \\
\hline $\begin{array}{c}\text { Tool Nose Radius } \\
(E)\end{array}$ & $\mathrm{mm}$ & $\mathrm{r}$ & 0.4 & 0.4 & 0.8 & 0.8 \\
\hline
\end{tabular}

Table 3: Assignment Of The Levels To The Factors ( $\mathrm{Si}$ Composition)

\begin{tabular}{|c|c|c|c|c|c|c|}
\hline Cutting & \multirow{2}{*}{ Unit } & \multirow{2}{*}{ Notation } & \multicolumn{5}{|c|}{ LIMITS } \\
\cline { 4 - 8 } Parameters & & Level 1 & Level 2 & Level 3 & Level 4 \\
\hline Feed rate $(A)$ & $\mathrm{mm} / \mathrm{rev}$ & $\mathrm{f}$ & 0.1 & 0.15 & 0.2 & 0.25 \\
\hline Speed $(B)$ & $\mathrm{RPM}$ & $\mathrm{N}$ & 500 & 1000 & 1500 & 2000 \\
\hline Depth of cut $(C)$ & $\mathrm{mm}$ & $\mathrm{d}$ & 0.25 & 0.5 & 0.75 & 1 \\
\hline $\begin{array}{c}\text { Material } \\
\text { Composition }(D)\end{array}$ & $\%$ & $\% \mathrm{Si}$ & 0.2 & 0.325 & 0.45 & 0.575 \\
\hline $\begin{array}{c}\text { Tool Nose } \\
\text { Radius }(E)\end{array}$ & $\mathrm{mm}$ & $\mathrm{r}$ & 0.4 & 0.4 & 0.8 & 0.8 \\
\hline
\end{tabular}

Table 4:Physical Layout for L16 Orthogonal Array (Mg Composition)

\begin{tabular}{|c|c|c|c|c|c|}
\hline $\begin{array}{c}\text { Expt. } \\
\text { No. }\end{array}$ & $\begin{array}{c}\text { Feed rate } \\
(\mathrm{mm} / \text { rev })\end{array}$ & $\begin{array}{c}\text { Speed } \\
(\text { RPM })\end{array}$ & $\begin{array}{c}\text { Depth of cut } \\
(\mathrm{mm})\end{array}$ & $\begin{array}{c}\text { Tool Nose radius } \\
(\mathrm{mm})\end{array}$ & $\begin{array}{c}\text { MC } \\
(\% \mathrm{Mg})\end{array}$ \\
\hline 1 & 0.100 & 500 & 0.250 & 0.400 & 0.500 \\
\hline 2 & 0.100 & 1000 & 0.500 & 0.800 & 0.625 \\
\hline 3 & 0.100 & 1500 & 0.750 & 0.400 & 0.750 \\
\hline 4 & 0.100 & 2000 & 1.000 & 0.800 & 0.875 \\
\hline 5 & 0.150 & 500 & 0.500 & 0.400 & 0.875 \\
\hline 6 & 0.150 & 1000 & 0.250 & 0.800 & 0.750 \\
\hline 7 & 0.150 & 1500 & 1.000 & 0.400 & 0.625 \\
\hline 8 & 0.150 & 2000 & 0.750 & 0.800 & 0.500 \\
\hline 9 & 0.200 & 500 & 0.750 & 0.400 & 0.625 \\
\hline 10 & 0.200 & 1000 & 1.000 & 0.800 & 0.500 \\
\hline 11 & 0.200 & 1500 & 0.250 & 0.400 & 0.875 \\
\hline 12 & 0.200 & 2000 & 0.500 & 0.800 & 0.750 \\
\hline 13 & 0.250 & 500 & 1.000 & 0.400 & 0.750 \\
\hline 14 & 0.250 & 1000 & 0.750 & 0.800 & 0.875 \\
\hline 15 & 0.250 & 1500 & 0.500 & 0.400 & 0.500 \\
\hline 16 & 0.250 & 2000 & 0.250 & 0.800 & 0.625 \\
\hline
\end{tabular}

Table 5:Physical Layout for L16 Orthogonal Array ( $\mathrm{Si}$ Composition)

\begin{tabular}{|c|c|c|c|c|c|}
\hline $\begin{array}{c}\text { Expt. } \\
\text { No. }\end{array}$ & $\begin{array}{c}\text { Feed rate } \\
(\mathrm{mm} / \text { rev })\end{array}$ & $\begin{array}{c}\text { Speed } \\
(\text { RPM })\end{array}$ & $\begin{array}{c}\text { Depth of cut } \\
(\mathrm{mm})\end{array}$ & $\begin{array}{c}\text { Tool Nose radius } \\
(\mathrm{mm})\end{array}$ & $\begin{array}{c}\text { MC } \\
(\% \mathrm{Si})\end{array}$ \\
\hline 1 & 0.100 & 500 & 0.250 & 0.400 & 0.200 \\
\hline 2 & 0.100 & 1000 & 0.500 & 0.800 & 0.325 \\
\hline 3 & 0.100 & 1500 & 0.750 & 0.400 & 0.450 \\
\hline 4 & 0.100 & 2000 & 1.000 & 0.800 & 0.575 \\
\hline 5 & 0.150 & 500 & 0.500 & 0.400 & 0.575 \\
\hline 6 & 0.150 & 1000 & 0.250 & 0.800 & 0.450 \\
\hline 7 & 0.150 & 1500 & 1.000 & 0.400 & 0.325 \\
\hline 8 & 0.150 & 2000 & 0.750 & 0.800 & 0.200 \\
\hline 9 & 0.200 & 500 & 0.750 & 0.400 & 0.325 \\
\hline 10 & 0.200 & 1000 & 1.000 & 0.800 & 0.200 \\
\hline 11 & 0.200 & 1500 & 0.250 & 0.400 & 0.575 \\
\hline 12 & 0.200 & 2000 & 0.500 & 0.800 & 0.450 \\
\hline 13 & 0.250 & 500 & 1.000 & 0.400 & 0.450 \\
\hline 14 & 0.250 & 1000 & 0.750 & 0.800 & 0.575 \\
\hline 15 & 0.250 & 1500 & 0.500 & 0.400 & 0.200 \\
\hline 16 & 0.250 & 2000 & 0.250 & 0.800 & 0.325 \\
\hline
\end{tabular}

\subsection{Taguchi analysis for Al6063T6 alloy}

The experimental results of the machining characteristics obtained for the turning parameters mentioned in table 3 are given in table 4.

Table 6:Experimental Results for Al6463 Alloy (Mg Composition)

\begin{tabular}{|c|c|c|c|c|c|}
\hline $\begin{array}{c}\text { Expt. } \\
\text { No. }\end{array}$ & $\begin{array}{c}\text { Surface } \\
\text { Roughness } \\
(\mu \mathrm{m})\end{array}$ & $\begin{array}{c}\text { Material } \\
\text { Removal Rate } \\
(\mathrm{mm} / \mathrm{min})\end{array}$ & $\begin{array}{c}\text { Machining } \\
\text { Time } \\
(\mathrm{min})\end{array}$ & $\begin{array}{c}\text { Machining } \\
\text { Force } \\
(\mathrm{N})\end{array}$ & $\begin{array}{c}\text { Power } \\
(\mathrm{W})\end{array}$ \\
\hline 1 & 1.454 & 263.627 & 0.800 & 12.500 & 0.010 \\
\hline 2 & - & - & - & - & - \\
\hline 3 & 3.947 & 2368.623 & 0.267 & 37.500 & 0.094 \\
\hline 4 & 1.651 & 3735.668 & 0.200 & 50.000 & 0.167 \\
\hline 5 & 4.118 & 697.457 & 0.533 & 37.500 & 0.047 \\
\hline 6 & 1.779 & 722.692 & 0.267 & 18.750 & 0.047 \\
\hline 7 & 2.896 & 4162.759 & 0.178 & 75.000 & 0.281 \\
\hline
\end{tabular}




\section{International Journal of Science and Research (IJSR) \\ ISSN (Online): 2319-7064 \\ Index Copernicus Value (2015): 78.96 | Impact Factor (2015): 6.391}

\begin{tabular}{|c|c|c|c|c|c|}
\hline 8 & 1.384 & 4205.807 & 0.133 & 56.250 & 0.281 \\
\hline 9 & 3.989 & 1562.157 & 0.400 & 75.000 & 0.125 \\
\hline 10 & 4.034 & 4104.664 & 0.200 & 100.000 & 0.333 \\
\hline 11 & 3.406 & 1456.694 & 0.133 & 25.000 & 0.125 \\
\hline 12 & 2.451 & 4224.562 & 0.100 & 50.000 & 0.333 \\
\hline 13 & 5.697 & 2597.469 & 0.320 & 125.000 & 0.260 \\
\hline 14 & 4.667 & 3865.906 & 0.160 & 93.750 & 0.391 \\
\hline 15 & 4.378 & 3841.076 & 0.107 & 62.500 & 0.391 \\
\hline 16 & 2.543 & 2642.394 & 0.080 & 31.250 & 0.260 \\
\hline
\end{tabular}

Table 7: Experimental Results for A16463 Alloy (Si Composition)

\begin{tabular}{|c|c|c|c|c|c|}
\hline $\begin{array}{c}\text { Expt. } \\
\text { No. }\end{array}$ & $\begin{array}{c}\text { Surface } \\
\text { oughness } \\
(\mu \mathrm{m})\end{array}$ & $\begin{array}{c}\text { Material } \\
\text { Removal Rate } \\
(\mathrm{mm} / \mathrm{min})\end{array}$ & $\begin{array}{c}\text { Machining } \\
\text { Time } \\
(\mathrm{min})\end{array}$ & $\begin{array}{c}\text { Machining } \\
\text { Force } \\
(\mathrm{N})\end{array}$ & $\begin{array}{c}\text { Power } \\
(\mathrm{W})\end{array}$ \\
\hline 1 & 2.021 & 449.452 & 0.800 & 12.500 & 0.010 \\
\hline 2 & 0.548 & 1652.729 & 0.400 & 25.000 & 0.042 \\
\hline 3 & 1.542 & 4071.504 & 0.267 & 37.500 & 0.094 \\
\hline 4 & 1.236 & 6867.977 & 0.200 & 50.000 & 0.167 \\
\hline 5 & 3.659 & 1357.115 & 0.533 & 37.500 & 0.047 \\
\hline 6 & 1.388 & 1399.898 & 0.267 & 18.750 & 0.047 \\
\hline 7 & 2.935 & 7519.488 & 0.178 & 75.000 & 0.281 \\
\hline 8 & 1.350 & 7778.835 & 0.133 & 56.250 & 0.281 \\
\hline 9 & 2.872 & 2690.955 & 0.400 & 75.000 & 0.125 \\
\hline 10 & 1.568 & 6864.804 & 0.200 & 100.000 & 0.333 \\
\hline 11 & 3.366 & 2685.685 & 0.133 & 25.000 & 0.125 \\
\hline 12 & 2.200 & 6607.900 & 0.100 & 50.000 & 0.333 \\
\hline 13 & 6.421 & 4545.384 & 0.320 & 125.000 & 0.260 \\
\hline 14 & 3.291 & 5923.866 & 0.160 & 93.750 & 0.391 \\
\hline 15 & 3.786 & 6556.553 & 0.107 & 62.500 & 0.391 \\
\hline 16 & 2.881 & 4829.256 & 0.080 & 31.250 & 0.260 \\
\hline
\end{tabular}

\section{Results and Discussion}

\subsection{Mg Composition}

The main objective of the experiment is to optimize the turning parameters (cutting speed, feed rate, speed and nose radius) to achieve low value of the cutting parameters.

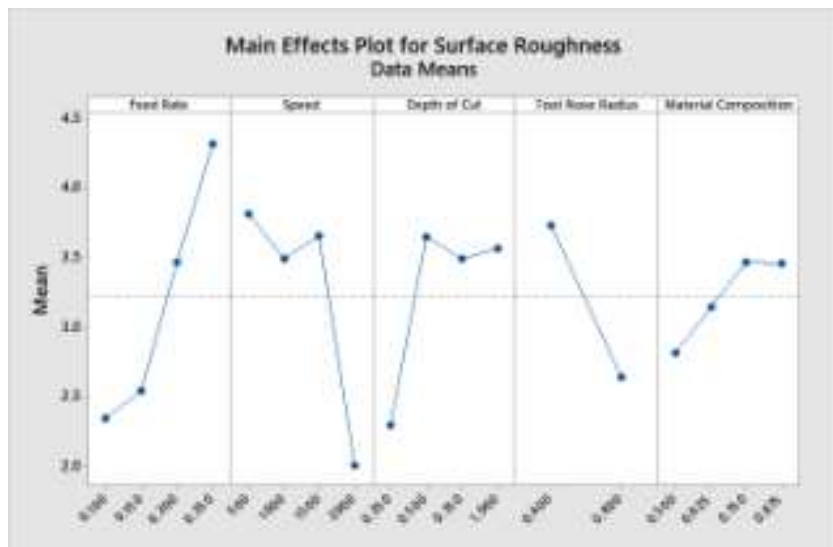

Figure 1: Main effects plot for surface roughness vs cutting parameters

Figure 1 gives the main effects plot for surface roughness vs cutting parameters to determine the optimum value. It is also

clear that surface finish has a high impact on the life of the machined components and hence the cutting parameter selection should result in a very low surface roughness value. From figure 1, it can be seen that the low feed rate of 0.1 $\mathrm{mm} / \mathrm{rev}$, high speed of $2000 \mathrm{RPM}$, low depth of cut of 0.25 $\mathrm{mm}$, high nose radius $0.8 \mathrm{~mm}$ and low magnesium composition of $0.5 \%$ gives low surface roughness values.

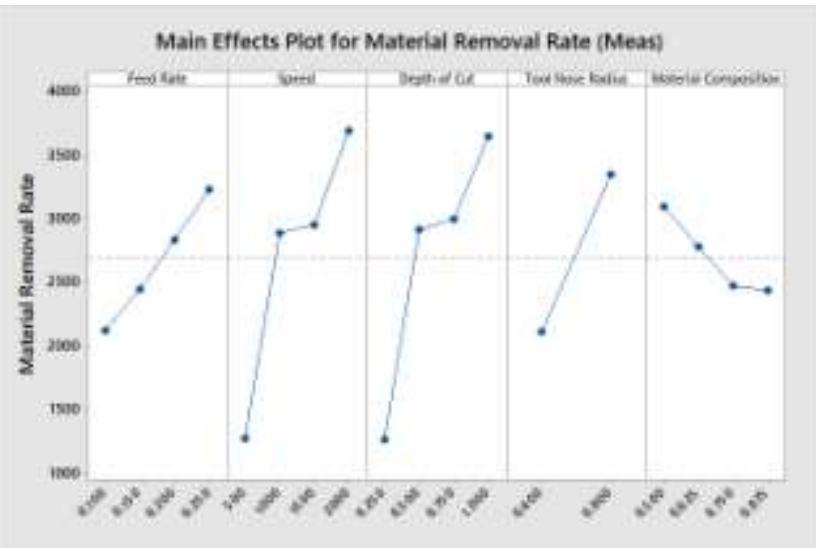

Figure 2: Main effects plot for Material Removal Rate vs cutting parameters

Figure 2 gives the main effects plot for material removal rate vs cutting parameters to determine the optimum value. It is also clear that material removal rate has a high impact on the processing time of the machined components and hence the cutting parameter selection should result in a very high material removal rate value. From figure 2, it can be seen that the high feed rate of $0.25 \mathrm{~mm} / \mathrm{rev}$, high speed of $2000 \mathrm{RPM}$, high depth of cut of $1 \mathrm{~mm}$, high nose radius of $0.8 \mathrm{~mm}$ and low magnesium composition of $0.5 \%$ gives high material removal rate values.

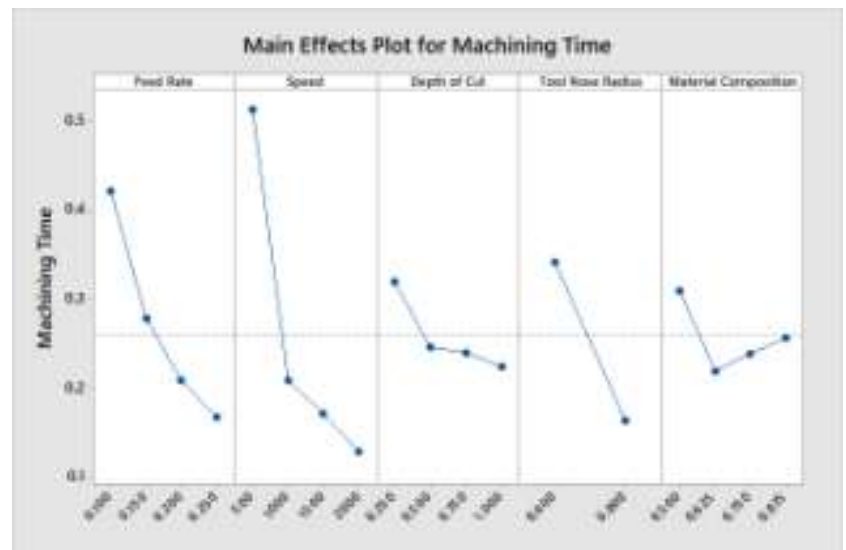

Figure 3: Main effects plot for Machining Time vs cutting parameters

Figure 3 gives the main effects plot for machining time vs cutting parameters to determine the optimum value. It is also clear that lower machining time has a high impact on the processing time of the machined components and hence the cutting parameter selection should result in a very low 


\section{International Journal of Science and Research (IJSR) \\ ISSN (Online): 2319-7064 \\ Index Copernicus Value (2015): 78.96 | Impact Factor (2015): 6.391}

machining time value. From figure 3, it can be seen that the high feed rate of $0.25 \mathrm{~mm} / \mathrm{rev}$, high speed of $2000 \mathrm{RPM}$, high depth of cut of $1 \mathrm{~mm}$, high nose radius of $0.8 \mathrm{~mm}$ and low magnesium composition of $0.625 \%$ gives least machining time values.

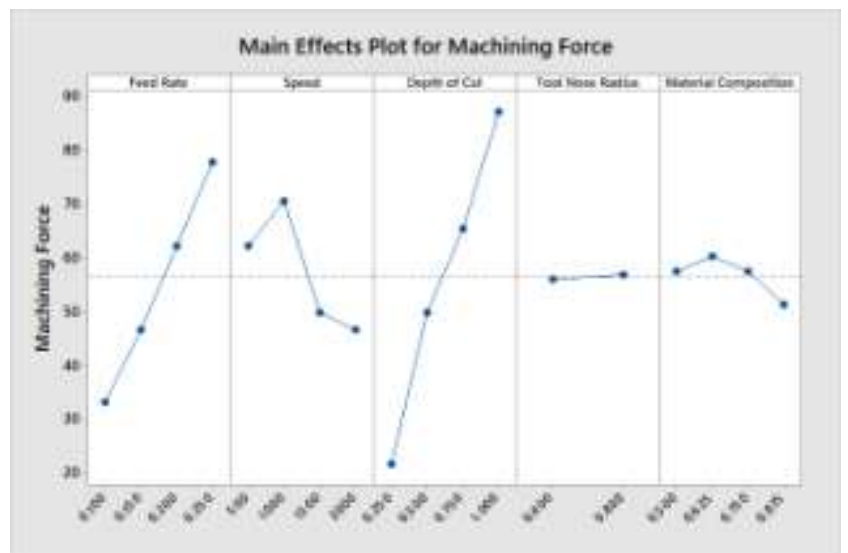

Figure 4: Main effects plot for Machining Force vs cutting parameters

Figure 4 gives the main effects plot for Machining force vs cutting parameters to determine the optimum value. It is also clear that lower machining force has a high impact on the life of the machined components, surface finish of the final product and hence the cutting parameter selection should result in a very low machining force value. From figure 3 , it can be seen that the low feed rate of $0.1 \mathrm{~mm} / \mathrm{rev}$, high speed of 2000 RPM, low depth of cut of $0.25 \mathrm{~mm}$, low nose radius of $0.4 \mathrm{~mm}$ and high magnesium composition of $0.875 \%$ gives least machining force values.

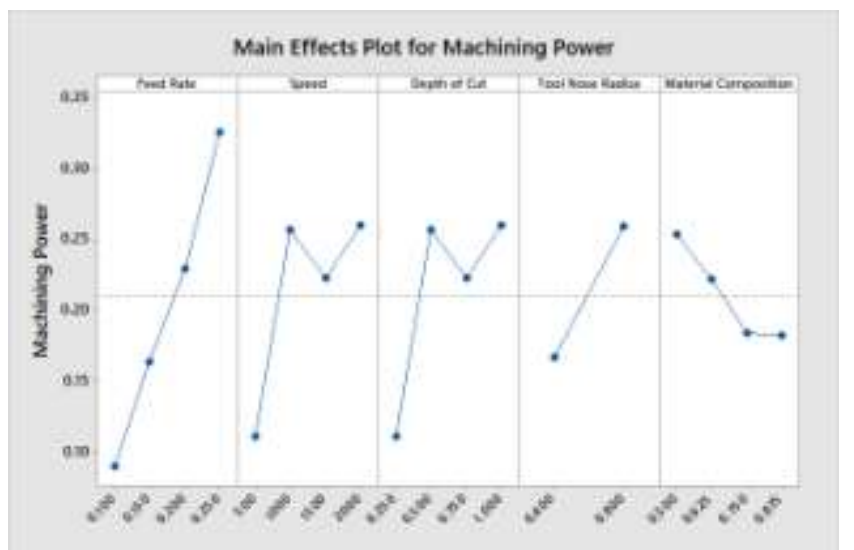

Figure 5: Main effects plot for Machining Power vs cutting parameters

Figure 5 gives the main effects plot for machining power vs cutting parameters to determine the optimum value. It is also clear that lower machining power has a high impact on the life of the machined components and also on the total cost of machining and hence the cutting parameter selection should result in a very low machining power value. From figure 5, it can be seen that the low feed rate of $0.1 \mathrm{~mm} / \mathrm{rev}$, low speed of
500 RPM, low depth of cut of $0.25 \mathrm{~mm}$, low nose radius of 0.4 $\mathrm{mm}$ and high magnesium composition of $0.875 \%$ gives least machining power values.

\subsection{Si Composition}

The main objective of the experiment is to optimize the turning parameters (cutting speed, feed rate, speed and nose radius) to achieve low value of the cutting parameters.

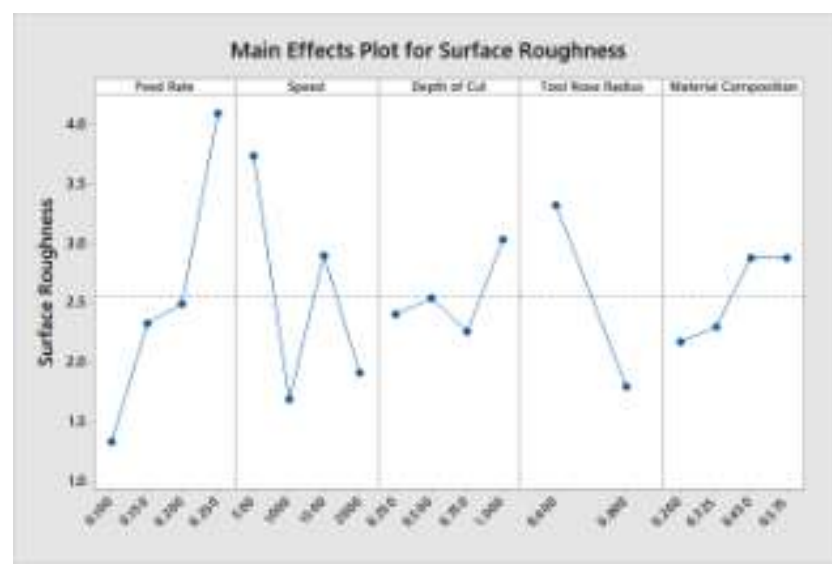

Figure 6: Main effects plot for surface roughness vs cutting parameters

Figure 6 gives the main effects plot for surface roughness vs cutting parameters to determine the optimum value. It is also clear that surface finish has a high impact on the life of the machined components and hence the cutting parameter selection should result in a very low surface roughness value. From figure 6, it can be seen that the low feed rate of 0.1 $\mathrm{mm} / \mathrm{rev}$, low speed of $1000 \mathrm{RPM}$, high depth of cut of 0.75 $\mathrm{mm}$, high nose radius $0.8 \mathrm{~mm}$ and low Silicon composition of $0.2 \%$ gives low surface roughness values.

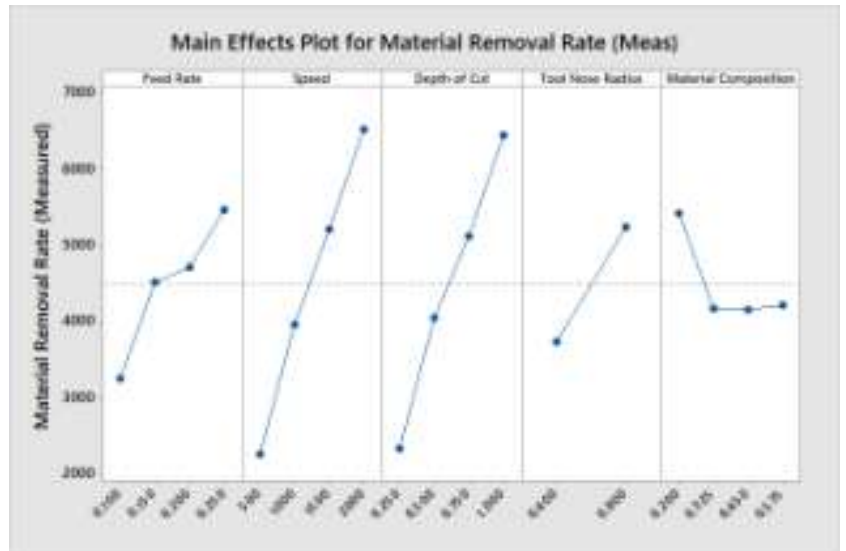

Figure 7: Main effects plot for Material Removal Rate vs cutting parameters

Figure 7 gives the main effects plot for material removal rate vs cutting parameters to determine the optimum value. It is also clear that material removal rate has a high impact on the processing time of the machined components and hence the 


\section{International Journal of Science and Research (IJSR) \\ ISSN (Online): 2319-7064 \\ Index Copernicus Value (2015): 78.96 | Impact Factor (2015): 6.391}

cutting parameter selection should result in a very high material removal rate value. From figure 7 , it can be seen that the high feed rate of $0.25 \mathrm{~mm} / \mathrm{rev}$, high speed of $2000 \mathrm{RPM}$, high depth of cut of $1 \mathrm{~mm}$, high nose radius of $0.8 \mathrm{~mm}$ and low silicon composition of $0.575 \%$ gives high material removal rate values.

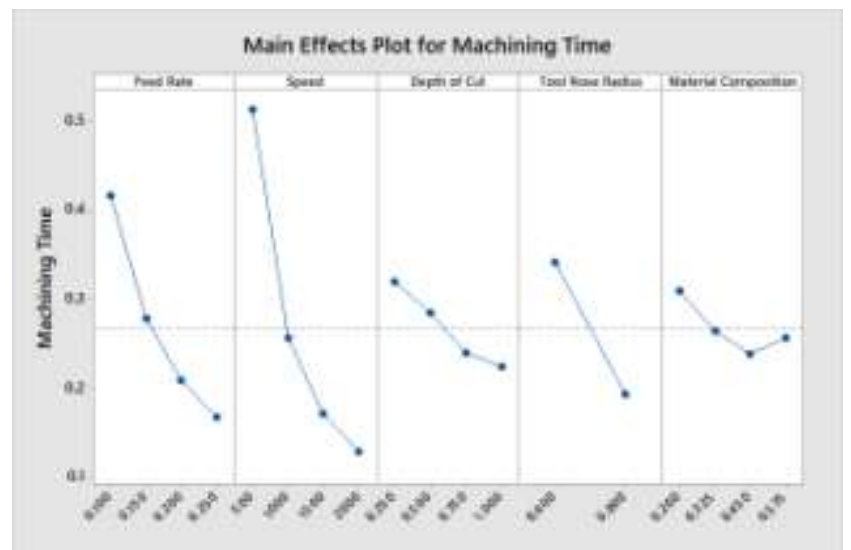

Figure 8: Main effects plot for Machining Time vs cutting parameters

Figure 8 gives the main effects plot for machining time vs cutting parameters to determine the optimum value. It is also clear that lower machining time has a high impact on the processing time of the machined components and hence the cutting parameter selection should result in a very low machining time value. From figure 8 , it can be seen that the high feed rate of $0.25 \mathrm{~mm} / \mathrm{rev}$, high speed of $2000 \mathrm{RPM}$, high depth of cut of $1 \mathrm{~mm}$, high nose radius of $0.8 \mathrm{~mm}$ and silicon composition of $0.45 \%$ gives least machining time values.

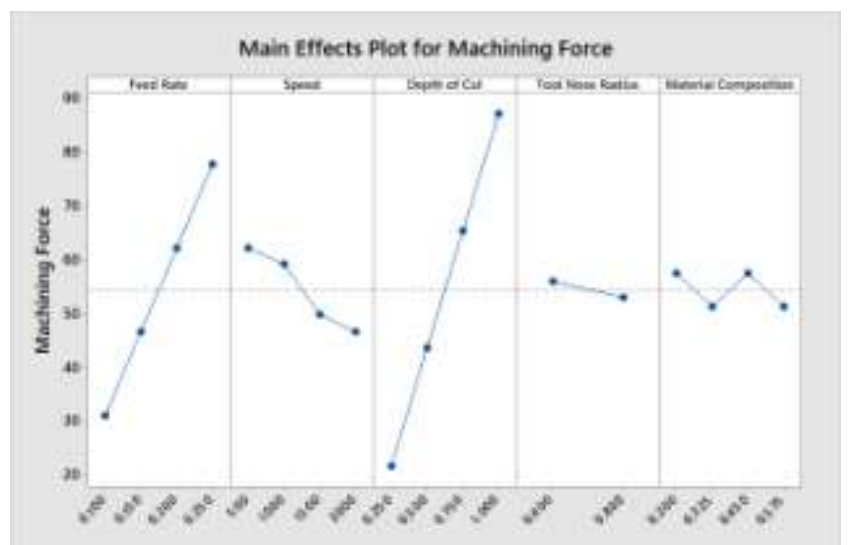

Figure 9: Main effects plot for Machining Force vs cutting parameters

Figure 9 gives the main effects plot for Machining force vs cutting parameters to determine the optimum value. It is also clear that lower machining force has a high impact on the life of the machined components, surface finish of the final product and hence the cutting parameter selection should result in a very low machining force value. From figure 9, it can be seen that the low feed rate of $0.1 \mathrm{~mm} / \mathrm{rev}$, high speed of 2000 RPM, low depth of cut of $0.25 \mathrm{~mm}$, high nose radius of
$0.8 \mathrm{~mm}$ and high Silicon composition of $0.575 \%$ gives least machining force values.

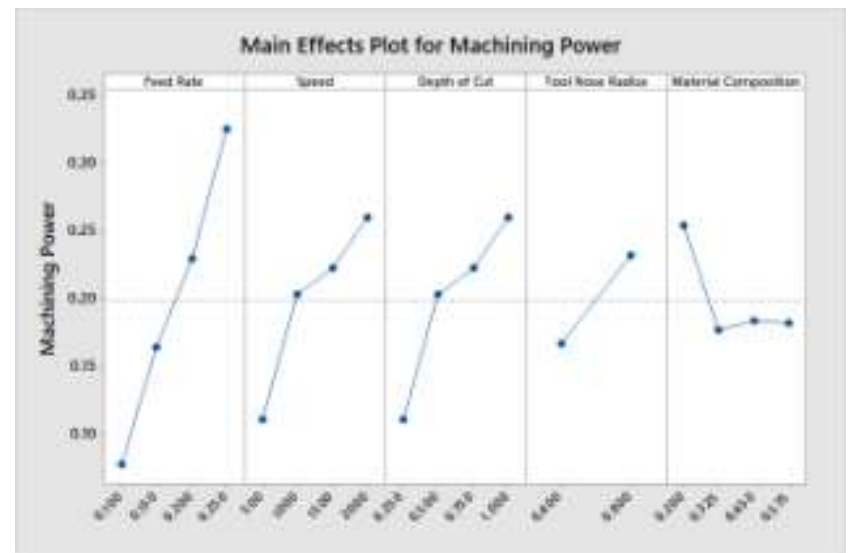

Figure 10: Main effects plot for Machining Power vs cutting parameters

Figure 10 gives the main effects plot for machining power vs cutting parameters to determine the optimum value. It is also clear that lower machining power has a high impact on the life of the machined components and also on the total cost of machining and hence the cutting parameter selection should result in a very low machining power value. From figure 10, it can be seen that the low feed rate of $0.1 \mathrm{~mm} / \mathrm{rev}$, low speed of 500 RPM, low depth of cut of $0.25 \mathrm{~mm}$, low nose radius of 0.4 $\mathrm{mm}$ and Silicon composition of $0.325 \%$ gives least machining power values.

\section{Conclusions}

An experimental investigation was carried out using Taguchi technique to reduce the number of experiments done for 5 factors and 4 levels. The experiment was conducted to optimize the cutting parameters for turning of aluminium alloy Al6463 on a CNC machine. The Taguchi analysis for each of the parameters (ie., Surface roughness, Material removal rate, machining time, machining force and machining power) was done to determine the optimum machining parameter setting.

The results obtained after the experimentation show that the feed rate has the highest influence on the machinability parameters followed by speed and depth of cut. Tool nose radius has very little influence on the machinability parameters.

\section{References}

[1] D.I. Lalwani, N.K. Mehta, P.K. Jain, 2008, "Experimental investigations of cutting parameters influence on cutting forces and surface roughness in finish hard turning", journal of materials processing technology 206 .

[2] El Baradie, M.A., 1997, Surface roughness prediction in the turning of high strength steel by factorial design of experiments. Mater. Process. Technol., vol. 67, p. 55-61. 


\section{International Journal of Science and Research (IJSR) ISSN (Online): 2319-7064}

Index Copernicus Value (2015): 78.96 | Impact Factor (2015): 6.391

[3] Yang.W.H. and Tarng.Y.S, 1998, "Design optimization of cutting parameters for turning operation based on the Taguchi method", Journal of material processing technology, 002E

[4] Arbizu, I.P., Perez, C.J.L., 2003, Surface roughness prediction by factorial design of experiments in turning processes. Mater. Process. Technol., vol. 143-144, p. 390396.

[5] Abouelatta, O.B., Mádl, J., 2001, Surface roughness prediction based on cutting parameters and vibrations in turning operations. Mater. Process. Technol., vol. 118, p. 269-277.

[6] Roy, R.K., 1990,"A Primer on the Taguchi method." Competitive Manufacturing Series, New York, USA

[7] C.Y. Nian, W.H. Yang, Y.S. Tarng, 1999,“'Optimization of turning operations with multiple performance characteristics", J. Mater. Process. Technol. 95, 90-96.

[8] W.S. Lin, B.Y. Lee, C.L. Wu, 2001, "Modeling the surface roughness and cutting force for turning", J. Mater. Process. Technol. 108, 286-293.

[9] H. Wang, S. To, C.Y. Chan, C.F. Cheung, W.B. Lee, 2010, "A theoretical and experimental investigation of the tool-tip vibration and its influence upon surface generation in single-point diamond turning", Int. J. Mach. Tools \& Manuf. 50, 241-252.

[10] Abouelatta, O.B., Mádl, J., 2001,"Surface roughness prediction based on cutting parameters and vibrations in turning operations", Mater. Process. Technol., vol. 118, p. 269-277

[11] W.H. Yang, Y.S. Tarng, 1998, "Design optimization of cutting parameters for turning operations based on Taguchi method", J. Mater. Process. Technol. 84, 112129.

[12] M. Marcos-Barcarena, M. Sebastian Perez, J. ContrerasSamper, M. Sanchez-Carrilero, M. Sanchez-Lopez, J. Sanchez-Sola, 2005, "Study of roundness on cylindrical bars turned of aluminium-copper alloys", UNS A92024, J. Mater. Process. Technol. 162-163, 644- 648.

[13] Y. Li, T. Ngai, W. Xia, Y. Long, D. Zhang, 2003, "A study of aluminium bronze adhesion on tools during turning", J. Mater. Process. Technol. 138, 479-483.

[14]R K Rajput, 2007, "Manufacturing technology", laxmi publications, New Delhi. 